\title{
RELACJA KS. M. SZWABIŃSKIEGO Z 1927 ROKU O SYTUACJI WYCHODŹSTWA POLSKIEGO W OKRĘGU LIÈGE (BELGIA)
}

Działalność Polskiej Misji Katolickiej w Brukseli (dalej: PMK) obejmowała terytorium Belgii ${ }^{1}$. Jej zorganizowanie ks. dr T. Kotowskiemu powierzył w styczniu 1926 r. ks. kard. prymas E. Dalbor ${ }^{2}$. Niemalże codziennie, z różnych kolonii napływały do rektora PMK w Belgii liczne prośby o umożliwienie stałej opiek duszpasterskiej przez polskiego kapłana ${ }^{3}$. W odpowiedzi na te żądania, ks. rektor Kotowski praktycznie w każdym liście apelował do Prymasa Polski o wydelegowanie do Belgii duchownych z kraju. W jednym z listów z dnia 14 lutego 1927 r. w pełnym rozpaczy tonie napisał:

Do obsłużenia mam dwadzieścia parę kolonji robotniczych4, 6 szkół polskich, wreszcie młodziez akademicką w Brukseli, Antwerpji, Gemloux, Louwain, Liège,

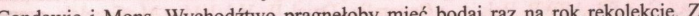
względu na to, że Bruksela jest najbliższą kościelną placówka polską, zwracają się tu z Holandji, a nawet Danji poselstwa i wychodźcy nieledwie błagając o polskiego

* Ks. Józef Szymański - dr historii Kościoła, adiunkt w Instytucie Badań nad Polonią i Duszpasterstwem Polonijnym KUL

s Akta Protektora Wychodźstwa Polskiego (dalej: APWP), Belgia - Generalia, Dział II, Vol I/44a, Ks. Tadeusz Kotowski, Do Jego Eminencji Najdostojniejszego Xiędza Metropolity GnieźnieńskoPoznańskiego, Prymasa Polski, Protektora Polskich Misji Zagranicznych, Raport z działalności Pol Misji Kat w Belgji od 15-I do 15-X. 1926 r

2 AAG, APP, APWP, Belgia - Generalia, Dział II, Vol I/44a, Bp. Piotr [Mańkowski], Do Jego Eminencji Najprzewielebniejszego Ksiedza Kardynała Prymasa E. Dalbora w Poznaniu, Włodzimierz, dnia 16 stycznia 1926 r. Nr. 36; Polska Misja Katolicka w Belgji, „Biuletyn Komitet Opieki Kulturalno - Społecznej dla Wychodztwa Polskiego w Belgii”, lipiec - sierpień 1926, s. 3 ; Polska Misja Katolicka w Belgji, Danji i Holandji, „Biuletyn Katolików Polskich w Belgji, Danji i Holandji”, 8/12 1927, s. 1.

${ }^{3}$ W. Rosowski, Ks. dr Tadeusz Kotowski-pierwszy rektor Polskiej Misji Katolickiej w Belgii, Studia Polonijne", 28 (2007) s. 154-160.

${ }^{4}$ Cytaty z zachowaniem oryginalnego stylu i składni. 
kapłana. Otrzymuję listy od różnych proboszczów o przyjazd lub przysłanie księdza. Ostatnio w diecezji Liège, z polecenia Kurji Biskupiej zaczeli objeżdżać nasze kolonje zakonnicy z Eupen i Malmedy z kazaniami niemieckimi. Kurja biskupia przestała się w ogóle do mnie zwracać, urażona bezskutecznością wszelkich próśb o stałych kapelanów /jak pisałem, Kuria wzięła na siebie utrzymanie materialne naszych księży/. Rozgoryczenie wśród wychodźtwa w Belgji i Holandji ogromne. [...] Niesłychanie to bolesne, że pomimo pewnego zainteresowania sie ostatnio sprawami misyjnemi w Polsce, Najdostojniejszy Episkopat nasz nie może znaleźć wśród masy kleru ludzi, którzyby zrozumieli konieczność ratowania naszych rodaków zagranicą od pewnej zguby. Przesłanie do Belgji bodaj 3-księży jest konieczne [...] W obecnych warunkach właściwie dalsze utrzymywanie Misji Kat. w Brukseli nietylko jest bezcelowe, ale wprost szkodliwe. Na poczatku miałem zupełne zaufanie czynników kościelnych. Od czasu jednak, kiedy zrozumiano, że nie mam najmniejszego poparcia w kraju, przestano się do mnie w ogóle zwracać. Czego dowodem jest na przykład wprowadzenie bez mojej wiedzy niemieckiego duszpasterstwa dla Polaków w diecezji Liège"s.

Starania rektora o polskich duszpasterzy w lutym 1927 r. poparł także Związek Centralnych Towarzystw Polskich w Belgii ${ }^{6}$. W odpowiedzi na te dramatyczne apele, Prymas Polski kolejny raz zwrócił się do niektórych biskupów polskich o wydelegowanie księży do pracy w duszpasterstwie wśród Polaków zagranicą. $\mathrm{Z}$ powodu, jak to określił prymas, niedostatecznej liczby kapłanów w kraju i na emigracji nie mógł zadośćuczynić wspomnianym apelom? ${ }^{7}$. Niemniej od wikariusza kapitulnego we Włocławku ${ }^{8}$ otrzymał zapewnienie o oddelegowaniu do Belgii ks. Stanisława Kozłowskiego?.

${ }^{5}$ AAG, APP, APWP, Belgia - Generalia, Dział II, Vol I/44a, Odpis. X. Tadeusz Kotowski Rektor P.M.K. w Belgji Do jego Eminencji Najdostojniejszego Księdza Prymasa Polski, Bruxelles, 14 lutego 1927; Por. Polacy w Belgji, „Biuletyn Katolików Polskich w Belgji, Danji i Holandji”, 8/12 1927, s. 5; Ks. J. Szymański, Poczatki Polskiej Misji Katolickiej w Belgii, „Roczniki Teologiczne” $52(2005)$ z. 4, s. $92-93$

${ }^{6}$ AAG, APP, APWP, Belgia - Generalia, Dział II, Vol I/44a, M. Grzelak, prezes Zarządu Centralnego Zwiazku Towarzystw Polskich w Belgji, Do Jego Eminencji Najdostojniejszego Księdza Kardynała Prymasa Polski, Boux dnia 13. II. 1927 r.

${ }^{7}$ AAG, APP, APWP, Belgia - Generalia, Dział II, Vol I/44a, Ks. Prymas A. Hlond. Do Zarząu Centralnego Związku Towarzystw Polskich w Belgi, 15. II. $1927 \mathrm{r}$

${ }^{8}$ AAG, APP, APWP, Belgia - Generalia, Dział II, Vol I/44a, Ks. Tadeusz Kotowski Rektor P.M.K. w Belgji, Przewielebny Ksiądz Prałat Zborowski, Kancelarja Prymasa Polski, Poznań, Bruksela, 24 lutego 1927; Archiwum Diecezji Włocławskiej, Zespół Archiwum Kurii Diecezjalnej we Włocławku, Dział Personalny, Akta ks. Kozłowskiego Stanisława 1890-1942, sygn. KKDWł pers. 149

${ }^{9}$ Ur. 24 IV 1890 r. w Mniszewie, w ziemi radomskiej. Syn Ignacego i Karoliny z Szostaków. Wykształcenie zdobywał od 1905 r. w zakładzie wychowawczo-naukowym „Nazaret” księcia Michała Radziwiłła w Warszawie. Z uwagi na chęć podjęcia studiów wyższych z pedagogii, podjął starania o uzyskanie niezbędnej do tego matury państwowej. W tym celu zapisał się jako wolny słuchacz na Uniwersytet Kijowski, pełniąc równocześnie obowiazki nauczyciela w szkole polskiej utrzymywanej przez Macierz Polska. Po trzech latach pobytu w Kijowie powrócił do Warszawy. Podczas wakacji, które spędzał w parafii Wąsosze (diec. włocławska), z uwagi na działania wojenne rosyjsko-pruskie, które uniemożliwiły mu powrót do Warszawy, we wrześniu 1915 zgłosił się do Seminarium Duchownego we Włocławku. Po przyjęciu święceń kapłańskich 13 VI 1920, podjał obowiązi wikariusza w Rzgowie. 21 VI 1921 został powołany przez bpa S. Ździtowieckiego na
Na terenie Belgii najbardziej potrzebowały stałego kapelana polskie kolonie w Liège ${ }^{10}$. Dlatego też rektor PMK w Brukseli, po otrzymaniu 2 marca wiadomości o przydzieleniu do Belgii ks. Kozłowskiego, od razu postanowił powierzyć mu stanowisko kapelana wychodźstwa polskiego w tej diecezji ${ }^{11}$. W ciągu kilku dni ks. Kotowski załatwił wszelkie formalności zwiazane z podjęciem obowiązków duszpasterskich przez ks. Kozłowskiego ${ }^{12}$. Ostatecznie ta nominacja nie doszła do skutku ze wzgledów zdrowotnych. Rektor PMK w Belgii niezwłocznie powiadomił o tym Prymasa Polski ${ }^{13}$, jak również bpa włocławskiego, który na to miejsce

stanowisko sekretarza gen. katolickich stowarzyszeń żeńskich na terenie diecezji. Z uwagi na zamiłowanie do pracy duszpasterskiej poprosił o cofnięcie tej decyzji i podjął obowiązki wikariusza parafii św. Mateusza w Pabianicach.

Wielokrotnie prosił biskupa o zgode na podjęcie dalszych studiów teologicznych. 13 X 1922 Wal wiazki te podją dopiero 1 grudnia.

Jesienią 1924 podjął studia specjalistyczne na wydziale teologicznym w Warszawie. Trudności formalne z przyjęciem na uniwersytet, wymusiły jeszcze tego samego roku kontynuowanie studiów w Rzymie. W maju 1926 brał udział w kongresie eucharystycznym w Chicago. 9 VII 1926 uzyska dorat z o dok. W 1927 by kap rężone nauką zdrowie. Po powrocie do kraju podjął obowiązki wikariusza w katedrze i od wrześni prefekta w Gimnazjum Żeńskim Władysławy Aspisówny. Wkrótce został przeniesiony do szkoły technicznej. 19 VI 1929 został wikariuszem w Przedczu, a 14 grudnia proboszczem w Korczewie Od 6 VII 1940 pracował jako proboszcz w Grzegorzewie.

26 VIII 1940 został aresztowany i wywieziony do Szczyglina, a 29 sierpnia do Sachsenhausen. 14 XII został przeniesiony do Dachau (nr obozowy 22669). Na wiosnę został włączony do grupy wieźniów przeznaczonych na zagazowanie. Zginął 12 X 1942.

Archiwum Diecezji Włocławskiej, Zespół Archiwum Kurii Diecezjalnej we Włocławku, Dział Personalny, Akta ks. Kozłowskiego Stanisława 1890-1942, Sygn. KKDWł pers. 149; S. Librowski, Ofiary zbrodni niemieckiej spośród duchowieństwa diecezji wloclawskiej 1939-1945, Włocławek 1947, 77-79; E. Weiler, Die Geistlichen in Dachau sowie in anderen Konzentrationslagern und in Gefängnissen, Mödling 1971, s. 373.

${ }^{10}$ AAG, APP, APWP, Belgia - Generalia, Dział II, Vol I/44a, Ks. Tadeusz Kotowski Rektor P.M.K. w Belgji, Informacje o kapelanji w Liège, Załącznik, Bruxelles, le 11 marca 1927.

$"$ AAG, APP, APWP, Belgia - Generalia, Dział II, Vol I/44a, Ks. Tadeusz Kotowski Rektor PMK. w Beloji, Kancelarja J.Em. Prymasa Polski, Poznań, Bruxelles, 11 marca 1927.

${ }_{12}$ AAG, APP, APWP, Belgia - Generalia, Dział II, vol. I/44a; Rektor Kotowski do Kancelarii Prymasa Polski, Bruksela, 11 marca 1927 r., tamże, Rektor Kotowski do Kancelarii Prymasa Polski, Bruksela, 18 marca $1927 \mathrm{r}$.,

${ }^{13}$ AAG, APP, APWP, Belgia - Generalia, Dział II, Vol I/44a, Ks. Tadeusz Kotowski Rekto PM.K w Belgji, Kancelarja Jego Eminencji Prymasa Polski, Poznań, Bruxelles, 18 marca 1927. 
wyznaczył ks. Michała Szwabińskiego ${ }^{14}$. W sprawie jak najszybszego jego przyjazdu rektor monitował 7 czerwca Kancelarię Prymasa Polski ${ }^{15}$.

W 1927 r. stałe duszpasterstwo na terenie Belgii zostało zorganizowane w następujących parafiach: Liège, Cheratte, Montegné, Micheroux, Winterslag, Waterschei, Peronnes i Boussu-Bois. W jego organizację i bezpośrednio w pracę duszpasterską zaangażował się ks. rektor T. Kotowski i ks. M Szwabiński, ich działania wspierali w okresie wakacyjnym kapłani z Polski ${ }^{16}$

Stan i sytuację Wychodźstwa polskiego w okręgu Liège, egzemplifikuje relacja ks. M. Szwabińskiego skierowana Do Prześwietnej Kurii Biskupiej we Włocławku, uzupełniona ręcznie wykonaną mapą z wskazaniem odległości i wielkości kolonii polskiej. Zachowano oryginalną ortografię, styl i składnię.

Dokument oryginalny jest przechowywany w formie rękopisu w Archiwum Diecezji Włocławskiej. Zespół Archiwum Kurii Diecezjalnej we Włocławku. Dział Personalny. Akta ks. Szwabińskiego Michała 1901-1942. Sygn. KKDWł pers. 340 , s. $47-54$

${ }^{14}$ Ur. 8 IX 1901 w Nadrenii (pót-zach. Niemcy). Syn Tomasza i Cecylii z d. Piatek. W latach 1913-1919 uczył sie w Holandii, w Kolegium Św. Karola w Valkenburgu prowadzonym przez oblatów. W 1920 wstąił do Seminarium Duchownego we Włocławku. Święcenia kapłańskie przyjął 29 VI 1924. Po święceniach pracował jako wikariusz w parafii Parzno, od 20 VIII 1924 -św. Stanisława we Włocławku, od 25 VI 1925 był prefektem szkół powszechnych i kapelanem szpitala w Sieradzu. Od 26 lipca 1927 podjął obowiazki duszpasterskie wśród wychodźstwa polskiego w Liège (Belgia). Od 1 VII 1932 objał obowiązki wikariusza parafii św. Jana Chrzciciela we Włocławku, a od 19 IX został prefektem w zawodowej szkole dokształcajacej. W drugiej połowie 1932 notowany był w dokostał prefektem w zawodowej szkole dokształcającej. W drugiej połowie 1932 notowany był w doZawodowego. 15 VI 1934 otrzymał nominację na administratora parafii Grabkowo. 6 X 1941 został aresztowany i umieszczony w Klasztorze Salezjanów w Lądzie, a $30 \mathrm{X}$ tr. przewieziony do Dachau (nr obozowy 28414). Na wiosnę 1942 został włączony do grupy więźniów przeznaczonych na zagazowanie $28 \mathrm{~V} 1942$

Za działalność społeczną i posługę duszpasterską w 1938 został odznaczony Złotym Krzyżem Zasługi. Archiwum Diecezji Włocławskiej, Akta personalne ks. M. Szwabińskiego, sygn. 340 k. 106; S. Librowski, Ofiary zbrodni niemieckiej spośród duchowieństwa diecezji wlocławskiej 1939-1945, Włocławek 1947, s. 148; K. Rulka, Szwabiński Michal, w: Wloclawski Slownik Biograficzny, red. S. Kunikowski, T. III, Włocławek 2005, s. 177-178; J. Modrzejewski, Szwabiński Michal, w: Kazimierz Wielki oraz niepospolici z Kowala i okolic. Slownik biograficzny, Kalendarium, red, Z. J. Zasada, B. Ziółkowski, Włocławek - Kowal 2006, s. 223-224; E. Weiler, Die Geistlichen in Dachau sowie in anderen Konzentrationslagern und in Gefängnissen, Mödling 1971, s. 657; Zmiany $w$ diecezji. Ks. M. Szwabiński prefekt $w$ Sieradzu, kapelanem dla wychodźstwa polskiego w Belgii, „Kronika Diecezji Włocławskiej” 5(1927) T. 21, s. 147.

${ }^{15}$ AAG, APP, APWP, Belgia - Generalia, Dział II, Vol I/44a, Ks. Tadeusz Kotowski Rektor P.M.K. w Brukseli, Kancelarja J.E.X. Kardynała Prymasa Polski, Wydział Opieki nad Polakami Zagranica, Poznań, Bruxelles, le 2 sierpnia 1927. „X. Szwabiński przybył do Brukseli 26/VII 27”.

${ }^{16}$ AAG, APP, APWP, Belgia - Generalia, Dział II, Vol I/44a, Ks. T. Kotowski Rektor P.M.K. w Brukseli, Sprawozdanie z działalności Polskiej Misji Katolickiej w Brukseli za kwartał od 1-go czerwca do 1-go września 1927 r.

\section{Do Prześwietnej Kurii Biskupiej}

we Włocławku

Niniejszym proszę uprzejmie Prześwietną Kurię Biskupią o łaskawe przyznanie i przekazywanie mi pensji wikariuszowskiej. Motywy podane są w sprawozdaniu.

Kreśląc wyrazy głębokiej czci i przywiązania pozostaję z poważaniem

Liège $2481927 \mathrm{r}$.

Ks. M. Szwabińsk

75 rue Jean d'Outre-Mense

\section{2}

Do Prześwietnej Kurii Biskupiej

we Włocławku

Stanąwszy na miejscu nowej przez, Prześwietną Kurię Biskupią wyznaczonej mi pracy pośpieszam podzielić się wrażeniami i zdać sprawozdanie z podjętej działalności. Teren mojej działalności jest diecezja Liège - $\mathrm{i}$ tylko na ten obszar otrzymałem jurysdykje, i to wikariuszowska. Chwilowo jednak obsługuję zasadniczo tylko dwie kolonie polskie - a mianowicie Micheroux i Cheratte - kolonie zależne od kopalni Hapard, która to kopalnia mnie fatycznie utrzymuje. Jest to dyskretna umowa między powyższą kopalnią Misją Polską w Brukseli - tzn. Kuria Belgijska ani rząd nie są o tym poinformowani. Są oni zdania, iż mnie utrzymują Księża Biskupi Polscy - względnie rząd polski. Stosunek mój względem Kurii Biskupiej i proboszczów jest tym sposobem więcej niezależny.

$\mathrm{Z}$ drugiej strony jednak uzależniony jestem w swojej pracy duszpasterskiej od dyrekcji kopalni Hapard, która utrzymując specjalnego księdza dla swych robotników polskich żąda, aby on tylko nimi się zajmował. Polacy znów będący zatrudnieni w kopalniach należących do Kompanii Hapard, przedstawiają licznie sporawą część wszystkich Polaków mieszkajacych w Liège i okolicy. Reszta pozostaje więc i nadal bez stałej opieki duszpamieszkających w Liège i okolicy. Reszta pozostaje więc i nadal bez stałej opieki duszpai braku specjalnego kościoła dla Polaków niemożliwe. Urządza się jednak nabożeństwa popołudniowe $\mathrm{z}$ kazaniem i dające sposobność do spowiedzi.

Praca duszpasterska idzie na ogół bardzo trudno. Robotnicy rekrutujący się przeważnie ze wsi - większa część jest z diecezji włocławskiej i częstochowskiej - odwykli od księdza i Kościoła. Musiał to być element najgorszy, który wyemigrował skoro zapomnieli już o swych powinnościach religijnych.

W Cheratte np. na 400 dorosłych - mimo dwukrotnej osobistej wizyty w ich mieszkaniach i zaproszenia z mej strony na msze św. policzyłem o porze bardzo dogodnej odprawianej - było ośmiu. W innych koloniach jest nieco lepiej - ale daleko jeszcze od frekwencji normalnej. Jak wythumaczyć smutny ten fakt? Czy brakiem ubrania? Wszyscy noszą się wspaniale - wzbudzając nawet podziw u belgijskich robotników. (Ostatnia moda 
nakazuje nosić ołówek lub wieczne pióro w zewnętrznej kieszonce marynarki bez względu na umiejętność pisania.

Czy brakiem czasu? Nie - praca dla wszystkich kończy się albo o 3ciej po południu albo o 10 wieczorem. W sobotę czy daleką i żmudną drogą do Kościoła ? Też nie - drogi wspaniałe - a najdalej do kościoła mają półtora kilometra.

Powody są innego rodzaju.

1. Powód psychologiczny.

Większość tutejszych robotników rekrutuje się ze wsi. W Polsce na swoich dwóch - trzech morgach żyli w nędzy i biedzie - nie mieli się w co ubrać - żyli jak zwierzęta. Tutaj stają się materialnie dobrze. Zarabiają od 35-50 franków na dzień (około 10 zł). O ile są z rodziną otrzymują najczęściej mieszkanie kopalniane (domek piętrowy - składający się z pięciu pokoi - ogródka i stajenki). Kopalnia szanuje więcej polskiego robotnika niż włoskiego, czeskiego i in. zapewniał mnie o tym dyrektor kopalni. Polacy o tym wiedza. Ślub cywilny jest wystarczający dla otrzymania mieszkania i dodatku rodzinnego. Proboszcz belgijski darmo chrzci - więcej jeszcze - bo do domu przychodzi prosząc i błagając o ochrzczenie dziecka - a gdy zdarzy się pogrzeb to kopalnia wszystko załatwia.

Urośli tutaj jakoś Polacy - „zapomnieli”. A uprzejmość belgijskiego ks. Proboszcza ich w tym utwierdza - On pierwszy bowiem kłania się wszystkim - nawet dzieciom a więc i Polakom. A Polak, który w Polsce przed swym ks. Proboszczem czapką ziemię zamiatał, a gdy był w potrzebie w pas sie zginał i do kolan swemu ojcu duchownemu padał, tutaj od niechcenia tylko przykłada palce do czoła albo łaskawie głową kiwnie, gdy jemu ksiądz proboszcz się ukłoni.

Zwiedzając kolonie polskie nie spotkałem prawie nigdzie objawów grzeczności należnych kapłanowi. Owszem w niektórych miejscach przyjęto mnie nie tylko chłodno ale nawet wrogo.

W mig zrozumiał więc tutejszy robotnik polski i zorientował się, że ksiądz mu mniej potrzebny jak w Polsce, że tutaj inaczej. Ponieważ w umyśle człowieka mało inteligentnego zachodzi ścisły związek między zasadami wiary a przedstawicielem tejże wiary, a z drugiej strony oddala dobrobyt ludzi słabej wiary i pod względem wiary mało uświadomionych od Boga. Więc tutaj szukać musimy powodu zaniedbania się tutejszych Polaków w swych obowiązkach religijnych.

2. Powód: Agitacja socjalistyczna i komunistyczna.

Statystyka wykazuje, że właśnie w Liège jest najwiecej socjalistów i komunistów z całej Belgii. Socjaliści tutejsi otrzymali z Moskwy pożyczkę na kupno własnego lokalu. Odpowiedni kontrakt był nawet opublikowany w tutejszych dziennikach. Policja zamknęła niedawno temu szkołę komunistyczną w Seraing (przedmieście Liège) założoną celem kształcenia komunistów polskich.

Konsul polski w Brukseli pokazywał mi listę komunistów polskich zamieszkałych w Liège. Sam stwierdziłem, że polscy robotnicy otrzymują bibułę komunistyczną z Moskwy i Chicago. Żydów na tutejszym uniwersytecie i instytutach jest przeszło sto. Jest nawet jeden instytut techniczny żydowski, gdzie patent za pieniądze można dostać.

W syndykacie socjalistycznym jest duży procent Polaków.
Prawie wszyscy którzy w Polsce należeli do partii chłopskiej i związku robotników rolnych - należą tutaj do syndykatu socjalistycznego, mimo iż istnieje na miejscu dość silny syndykat katolicki. W demonstracjach na cześć Włochów Sacco i Vanzetti ${ }^{17}$ Polacy thumnie wzieli udział, tak iż nawet dzienniki tutejsze na to zwróciły uwagę. Zauważyłem w pochodzie bardzo wiele Żydków polskich.

3. Powód: Wzgląd narodowy.

Skarżyli się przede mną księża belgijscy, iż Polacy nie przychodzą wcale na mszę św. Zapytawszy się Polaków o powód, otrzymałem odpowiedź, że to przecież nie polska msza św., a kazanie to ks. proboszcz takim „cudacznym” językiem mówi, że aż pękać od śmiechu, a organy to grają aż się chce człowiekowi „tańcować” - to nie tak jak u nas - więc po co tam pójdziemy! To nie nasza wiara. Szukaj tutaj człowiecze argumentów (katechizacja, katechizacja i jeszcze raz katechizacja w kościele, katechizacja w szkole, nie przez nauczycieli i nauczycielki ale przez księży).

Nie chodzili wiẹc Polacy do Kościoła z początku dlatego, iż nie było nabożeństwa polskiego, a teraz nie chodzą bo odwykli. Ksieża proboszczowie z Polski nie poznaliby swoich parafian w Belgii. A ci, którzy przywykli być w swojej parafii alfą i omegą nie wytrzymaliby tutaj ani dnia.

A jednak trzeba wytrzymać a jak owieczki same nie przyjdą, trzeba je szukać. Wielką pomocą byłaby tutaj prasa i książka katolicka. Niestety o kolportaż bardzo trudno, ponieważ dzienniki i książki polskie są cztery razy droższe od belgijskich. Nie można więc rozrzucać gazet i książek polskich katolickich, jak to czynią socjaliści i komuniści ze swoją bibuła. A jednak leżą w redakcjach katolickich całe stosy wydanych gazet, a w księswoją bibuła. A jednak leżą w redakcjach katolickich całe stosy wydanych gazet, a w księgras narza. Proszę więc gor ją które jako dziennik katolicki a nie sko wielu jest $\mathrm{z}$ diecezji włocławskiej. Aby oszczędzić na opłacie pocztowej można wysyłać co drugi dzień, ale nie rzadziej - bo inaczej nie wzbudziłby zainteresowania.

Tak sie mają sprawy z robotnikami polskimi. Na szczęście trafiają się tutaj ludzie o złotym sercu, którzy za swych rodaków z płaczem mnie przepraszali, błagając mnie, abym został $\mathrm{i}$ ich nie opuszczał. Pociechy więc nie brak. Jestem głęboko przekonany że za łaska Boska wszystko się zmieni na lepsze.

Przechodze teraz do polskiego koła akademickiego. Polskich studentów katolików bedzie tutaj około stu. Studiuja na uniwersytecie, ale przede wszystkim na przeróżnych instytutach. Ponieważ jest czas wakacji więc wszyscy się porozjeżdżali. Zostali się tylko najbiedniejsi, którzy podczas wakacji, pracują na fabrykach, kopalniach etc. i w ten spo-

${ }^{17}$ Ferdinando „Nicola” Sacco (ur. 4 IV 1891 w Torremaggiore, zm. 23 VIII 1927) i Bartolomeo Vanzetti (ur. 11 VI 1888 w Villafalletto, zm. 23 VIII 1927) - anarchiści amerykańscy pochodzeni włoskiego. Przybyli do USA w 1908. Czynnie angażowali się w organizację strajków i demonwrosialem działalności godzacej w dobro puticzi iosianych przez nich alibi, bliczne i oskarzeni o napad rabunkowy i dwa mo wątpliwych dowodów, zostali skazani na śmierć. W obronie robotników stanęło wielu intelektualistów. Wyrok wykonano 23 VIII 1927. Gubernator Massachusetts M. Dukakis zrehabilitował Sacco i Vanzettiego 23 VIII 1977. 
sób nieco grosza sobie zarabiaja. Los niektórych jest naprawdę opłakany. Przyjechali ci mizeracy do Liège z zamiarem pracowania tutaj gdzie się da, aby w ten sposób zdobyć środki na utrzymanie i naukę. Ale o pracę bardzo trudno. A za mieszkanie i utrzymanie płacić trzeba.

Spotkałem już prawdziwych łazarzy wśród polskich studentów. Co miał - to sprzedał. Pani wymówiła mu mieszkanie, sypia gdzie może, je co od litościwych kolegów dostanie. Gdy dowiedzieli się iż przyjechałem i tutaj pozostane - w tej chwili zebrało się u mnie kilkunastu, tak jak Pijas - omnia tua secum portans błagając abym ich nędzą się zajął. Trzeba było przede wszystkim zaspokoić pretensje pań u których wszyscy zalegali z opłatą za mieszkanie, potem to bractwo nakarmić, niektóry z nich już od tygodni obiadu nie jadł - dalej poszukać im pracę. Dzisiaj pracują już wnet wszyscy i to przy budowach, na kolei, na kopalniach. Trzeba było ich widzieć gdy pierwszy raz wracali od pracy. Takie to bractwo zmęczone, zgarbione, wprost złamane, reece spuchnięte, twarze pokaleczone, ale humoru nie zgubili. Dzisiaj już się przyzwyczaili. Jednak co będzie, gdy praca się skończy, gdy nie będzie można pogodzić pracy z nauką? Konsulat Polski żadnych zasiłków nie daje motywujac to tym, iż przez dyrekcje uniwersytetów ostrzegał przed wyjazdem do Belgii tych studentów, którzy nie mając własnych funduszy liczą tutaj na pracę zarobkową. Samopomoc akademicka tutaj niewiele pomoże. Najsamprzód trudno tutaj jest o zebranie funduszy, bo społeczeństwo belgijskie ma swoich własnych studentów, a po drugie mówiono mi, iż bogatsi studenci polscy na których kieszeń przede wszystkim się liczy, nie chcą należeć do Samopomocy. Myśli się jednak o stworzeniu własnej bursy dla polskich studentów.

A jak się przedstawiają moje stosunki materialne?

Przez Misję Polską otrzymuję pośrednio z kopalni Hapard okrągłe 1000 fr. miesięcznie. Misja Polska opłaca też dwa pokoje umeblowane tj. 325 fr. miesięcznie. Utrzymanie jest jednak nadzwyczaj drogie. Za śniadanie - obiad - kolacje płacę 20 fr. Gdy się weźmie pod uwage jeszcze inne wydatki jak gazety, książki, „nieszczęśliwe” papierosy, do czego dochodza bezzwrotne pożyczki dla rodaków - to 1000 fr. na miesiac nie wystarczy. Innych dochodów jednak nie ma. Stypendia mszalne są znikome. Przy tym jest zwyczaj, że opłaca się ministranta i kościelnego. Jestem więc zmuszony prosić gorąco Prześwietną Kurię Biskupią o udzielenie i przekazywanie mi pensji wikariuszowskiej. Gdybym takowej nie otrzymał, to egzystencja moja byłaby wprost niemożliwa.

Załączam odpowiednie podanie do prześwietnej Kurii i nadzieję, iż Prześwietna Kuria Biskupia wchodząc w me położenie przychyli się łaskawie do mojej prośby.

Kreśląc wyrazy głębokiego uszanowania Pozostaje z poważaniem

Ks. M. Szwabiński

P.S. Otrzymałem właśnie list, od Polskiego Stowarzyszenia Kulturalno Oświatowego z Montegnée (Stowarzyszenie komunistyczne) z groźbą że o ile sam nie zaprzestanę pracy nad oszukiwaniem polskiego robotnika to stowarzyszenie ze swej strony znajdzie odpowiedni - choćby ostateczny sposób na udaremnienie tak demoralizującej pracy. List redagował polski Żyd. Pismo to przedtem oddałem do dyspozycji policji. Niebo zachmurza się więc-Ale przyjdzie słońce.
3

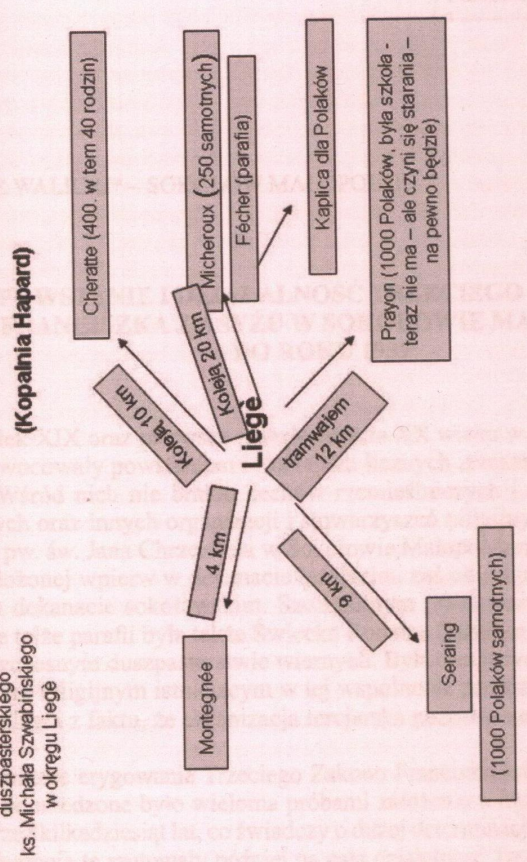

